\title{
Blood plasma concentrations of metabolic hormones and glucose during extended lactation in grazing cows or cows fed a total mixed ration
}

\author{
K. K. Delany, ${ }^{\star 1}$ K. L. Macmillan, $\dagger^{1}$ C. Grainger,‡ P. C. Thomson,§ D. Blache,\# K. R. Nicholas, ${ }^{\star}$ \\ and M. J. Auldist $\ddagger^{2}$ \\ ${ }^{*}$ CRC for Innovative Dairy Products, Department of Zoology, University of Melbourne, VIC 3010, Australia \\ †Department of Veterinary Science, University of Melbourne, Werribee VIC 3030, Australia \\ fFuture Farming Systems Research Division, Department of Primary Industries, Ellinbank VIC 3821, Australia \\ §Faculty of Veterinary Science, University of Sydney, Camden NSW 2570, Australia \\ \#School of Animal Biology, University of Western Australia, Crawley WA 6009, Australia
}

ABSTRACT

An experiment was conducted to measure the effect of diet on circulating concentrations of metabolic hormones and metabolites in cows undergoing extended lactations. Two groups of 6 Holstein-Friesian cows managed for lactations of $670 \mathrm{~d}$ were used in the experiment. One group was fully fed on a total mixed ration (TMR), whereas the other group grazed fresh pasture supplemented with grain $(\mathrm{P}+\mathrm{G})$. On 7 occasions between 332 and $612 \mathrm{~d}$ in milk, concentrations of metabolic hormones and glucose were measured in the blood plasma of each cow. Cows fed TMR gained more weight and body condition than $\mathrm{P}+\mathrm{G}$ cows, but did not produce more milk during the study period. Only 3 of the TMR cows continued to lactate until 612 $\mathrm{d}$ in milk compared with all 6 of the $\mathrm{P}+\mathrm{G}$ cows. Blood plasma from cows fed TMR had higher concentrations of glucose, insulin, glucagon, insulin-like growth factor 1 , and leptin, but lower concentrations of growth hormone, than that from $\mathrm{P}+\mathrm{G}$ cows. These changes were consistent with the preferential deposition of energy into adipose tissue at the expense of milk production and presumably were induced by a diet that provided precursors for gluconeogenesis that were in excess of the requirements for maintenance and prevailing milk production. The mechanism responsible for some TMR cows putting on excess weight and reducing or ceasing milk production is uncertain, but this observation has important implications for the nutritional management of cows in extended lactation programs.

Key words: pasture, hormone, total mixed ration, energy

Received July 9, 2010.

Accepted August 31, 2010.

${ }^{1}$ Present address: Gardiner Foundation, Melbourne, VIC 3000 Australia.

${ }^{2}$ Corresponding author: martin.auldist@dpi.vic.gov.au

\section{INTRODUCTION}

In the Australian and New Zealand dairy industries interest is increasing in managing cows for extended lactations of up to $670 \mathrm{~d}$, as opposed to the lactations of up to $300 \mathrm{~d}$ that traditionally have been used in pasture-based systems with seasonally concentrated calving patterns. This is partly because extended lactations alleviate the requirement for cows to conceive when they are in peak lactation, which often coincides with a negative energy balance (Auldist et al., 2007; Kolver et al., 2007; Grainger et al., 2009). Extendedlactation systems also capitalize on the higher milk prices garnered during winter in southern Australia, improve monthly cash flow, and better utilize farm labor across the year (Borman et al., 2004).

Variation exists among Holstein-Friesian cows in their capacity to sustain an extended lactation, which is influenced by the genetic strain of cow (Kolver et al., 2007), the propensity of the cow to gain body condition (Grainger et al., 2009), and level of intake beyond 300 DIM (Kolver et al., 2007; Grainger et al., 2009). In a comparison between Holstein-Friesian cows fed a TMR or a pasture-based diet supplemented with grain, Grainger et al. (2009) showed that although cows fed TMR produced more milk fat and protein during the first 300 DIM, fewer cows were able to sustain their lactation for the targeted 670 DIM. The TMR diet was instead associated with a tendency for cows to partition excess dietary energy toward body reserves at the expense of milk production.

Endocrine mechanisms coordinating the partitioning of energy during early lactation to minimize the effects of negative energy balance on cow health have been well characterized (Bauman and Currie, 1980; Collier et al., 1984; Ingvartsen and Anderson, 2000). Comparable mechanisms regulating energy partitioning beyond 300 DIM, however, when cows should be in positive energy balance, are not well understood. The objective of the current experiment was to extend the study of Grainger 
et al. (2009) by comparing plasma concentrations of hormones, glucose, and metabolites potentially related to lactation and energy transfer and storage in cows undergoing 670-d lactations but fed 2 different diets. The primary hypothesis was that, beyond 300 DIM, measured plasma hormones and metabolites would differ between cows fed either a TMR or a diet of pasture supplemented with grain. A second hypothesis was that observed differences would be consistent with differences in energy partitioning and lactational persistency in extended lactation.

\section{MATERIALS AND METHODS}

\section{Cows and Treatments}

The experiment used 12 cows from a larger experiment at the Department of Primary Industries (Ellinbank, VIC, Australia; latitude $38^{\circ} 14^{\prime} 36.4^{\prime \prime}$, longitude $\left.145^{\circ} 56^{\prime} 09.5^{\prime \prime}\right)$ that was designed to investigate the influence of level of nutrition on the capacity of cows to sustain a lactation of $670 \mathrm{~d}$ (Grainger et al., 2009). In that experiment, 96 spring calving Holstein-Friesian cows were divided into 8 groups of 12 cows. Cows were selected from the same research herd and allocated to groups so that groups were balanced for parity, calving date, BW, and, except for heifers, milk production in the preceding lactation (Baird, 1994; Grainger et al., 2009). Two of the 8 groups were randomly assigned to each of 4 treatments with varied lactation length and diet.

Only cows from 2 of the 4 treatment groups studied by Grainger et al. (2009) were used in the current experiment. Both groups received their dietary treatments simultaneously, commencing at the same time of the same calendar year. Briefly, these treatments were as follows: (1) pasture + grain $(\mathbf{P}+\mathbf{G})$, where cows were managed for a 670-d lactation and fed a diet based on pasture supplemented with grain (mostly barley, but occasionally triticale) and forage to provide a minimum daily dietary $\mathrm{ME}$ intake equivalent to $180 \mathrm{MJ} / \mathrm{cow}$. Cows received between 2.7 and $7.2 \mathrm{~kg}$ of DM grain/cow per d. This treatment corresponded to the "High 670" treatment described by Grainger et al. (2009); and (2) TMR, where cows were fed a TMR and managed for a 670-d lactation. The TMR comprised (DM basis) $17 \%$ grain (wheat, barley, or triticale), $14 \%$ canola meal, $34 \%$ alfalfa hay, $16 \%$ maize silage, $13 \%$ grass silage, $5 \%$ cereal straw, and $1 \%$ minerals, and was offered ad libitum until 440 DIM when the amount of TMR offered was reduced to decrease the incidence of overfeeding leading to excessive weight gain. The approximate ME concentration of the TMR was $11.0 \mathrm{MJ} / \mathrm{kg}$ of $\mathrm{DM}$, and mean DMI ranged between 18.5 and $24 \mathrm{~kg} /$ cow per d. The TMR cows also received an additional $1.8 \mathrm{~kg}$ of DM grain/cow per d at milking times. This treatment corresponded to the "Full TMR 670" treatment described by Grainger et al. (2009). For the duration of the experiment, cows receiving the TMR were housed in a barn with 2 open sides and were walked to the adjacent dairy twice daily for milking.

For the current study, 6 cows were selected from each of the $\mathrm{P}+\mathrm{G}$ and TMR treatments (3 cows from each replicate group of 12). Lactation length was extended by withholding breeding until 15 mo after calving. Any cow that had an average milk yield of less than 30 $\mathrm{kg} /$ wk for 2 consecutive weeks was dried off (milking ceased), after which they were no longer sampled. Cows that maintained production above this level were dried off after 670 DIM.

\section{Milk Yield and Composition}

Milk yield was measured daily for each cow using a DeLaval Alpro milk-metering system (DeLaval International AB, Tumba, Sweden). A composite sample was taken of the daily milk (p.m. and a.m.) from each cow using in-line milk meters once every 2 wk and tested for concentrations of fat and protein using an infrared milk analyzer (model 2000, Bentley Instruments, Chaska, $\mathrm{MN})$.

\section{Body Weight and Condition}

The BCS of each cow was recorded monthly by a trained observer using a modified version of the method described by Robins et al. (2003). This method for grazing cows in Australia describes an 8-point scale. This proved insufficient for some of the TMR cows (R. Stockdale, Department of Primary Industries; personal communication), and so the scale was increased to incorporate a ninth point for cows with greater BCS than 8. Cows were also weighed monthly.

\section{Blood Sample Collection}

Blood was sampled twice within a 14-d period at approximately 332 and 346 DIM, and then approximately every 2 mo for the remainder of the lactation (samples were collected at $332,346,392,441,520,569$, and 620 DIM). Because of the expected diurnal variation in plasma concentrations of metabolic hormones and glucose (Menzies, 2008), cows were sampled 7 times over $24 \mathrm{~h}$ at each occasion (at $0800 \mathrm{~h}, 1200 \mathrm{~h}, 1600 \mathrm{~h}, 2000$ h, $2400 \mathrm{~h}, 0400 \mathrm{~h}$, and $0800 \mathrm{~h}$ ).

Each sampling involved collecting approximately 10 $\mathrm{mL}$ of blood by venipuncture of the coccygeal (tail) vein into a Vacutainer tube containing $18 \mathrm{mg}$ of $\mathrm{K}_{2^{-}}$ 
EDTA (Provet Allhank Trading Co., Melbourne, VIC, Australia). Each sample was inverted several times and placed in ice water. A 2-mL aliquot was immediately added to $0.2 \mathrm{mg}$ of aprotinin (Sigma, Melbourne, VIC, Australia) in a glass Vacutainer for subsequent measuring of glucagon. Each blood sample was centrifuged within $30 \mathrm{~min}\left(1,800 \times g\right.$ for $15 \mathrm{~min}$ at $\left.4^{\circ} \mathrm{C}\right)$, and the plasma collected and stored at $-20^{\circ} \mathrm{C}$.

Further blood samples for glucose analysis were collected from the same venipuncture into 3-mL Vacutainers containing fluoro-oxide. Blood samples intended for NEFA and BHBA analyses were collected into plain 3-mL Vacutainers.

Glucose, insulin, glucagon, growth hormone $(\mathbf{G H})$, and leptin were measured in each of the 7 plasma samples collected at each sampling occasion (except glucagon, which was not measured in any samples at 332 or 346 DIM). For these analytes, data presented are predicted means of the concentrations in each of the 7 samples collected over the 24-h period. Concentrations of IGF-1 were measured in plasma samples obtained at $1600 \mathrm{~h}$ on each of the 7 sampling days (Obese et al., 2008). Concentrations of BHBA and NEFA were measured in 1 blood sample only, that from 332 DIM at $1200 \mathrm{~h}$.

\section{Hormone and Metabolite Assays}

Plasma insulin concentrations were measured using a commercial RIA kit (Coat-A-Count, ${ }^{125}$ I-coated tube radioimmunoassay, Diagnostic Products Corp., Los Angeles, CA) that has been validated for use in cattle (Williams et al., 1987) and used in studies with dairy cows (Moyes, 2004; Nocek et al., 2003). The intra- and interassay $\mathrm{CV}$ were 4.9 and $6.9 \%$, respectively.

Plasma glucagon concentrations were also measured using a commercial RIA kit (double-antibody radioimmunoassay, Diagnostic Products Corp.) that has been validated for use in cattle (Bremmer et al., 2000). The intra- and interassay CV were 4.9 and $9.8 \%$, respectively.

Plasma IGF-1 analysis was performed by ELISA as described by Obese et al. (2008). The intra- and interassay CV were 5.7 and $6.0 \%$, respectively.

Plasma leptin and GH concentrations were both measured by RIA as described by Blache et al. (2000) and Downing (1995), respectively. The intra- and interassay CV for leptin were 5.3 and $2.2 \%$, respectively, and 5.7 and $3.7 \%$ for $\mathrm{GH}$.

Serum was analyzed for NEFA, BHBA, and glucose in the commercial laboratories of Gribbles Veterinary Pathology, Clayton, VIC, Australia, using a Cobas Mira auto-analyzer (Roche Diagnostica, Basel, Switzerland). The NEFA were measured with the acetyl-CoA syn- thetase/peroxidase spectrophotometric method, BHBA was measured with the hydroxybutyrate dehydrogenase spectrophotometric method, and glucose was measured with the hexokinase spectrophotometric method.

\section{Statistical Analyses}

All statistical analyses were performed using GenStat Release 10.2 software. The NEFA and BHBA data, together with lactation data from 300 to 670 DIM (yields of milk, milk protein and fat, and concentrations of milk fat and protein) and changes in BW and BCS during the study period, were analyzed using a nonparametric 2-sample Mann-Whitney test.

The hormone and glucose data were analyzed using REML linear mixed models. The mixed model specified random effects for cow and included a correlation structure to allow for the repeated measurements on each cow. The fixed effects of the model were diet, sampling time, and sampling date. Interactions between the fixed effects of the mixed model were explored using 2-way interactions. Overall significance of fixed effects was assessed by Wald $\chi^{2}$ tests, and the differences in the model-based treatment mean estimates were assessed by additional Wald tests. The significance level of main effects were tested after dropping the interaction term from the mixed model and assessed by Wald $\chi^{2}$. The log-transformation of data was applied where appropriate to meet model requirements of normality and constant variance.

\section{RESULTS}

\section{Lactation Length}

All 6 cows in the $\mathrm{P}+\mathrm{G}$ group continued to lactate until at least the last blood sampling at 612 DIM compared with 3 of the TMR cows. One cow from the TMR group was dried off at 459 DIM and was replaced by a similar cow thereafter. Three of the $\mathrm{P}+\mathrm{G}$ cows completed the planned lactations of 670 DIM compared with 1 cow from the TMR group.

\section{Body Weight and Condition}

Mean BCS was greater $(P<0.001)$ for TMR cows than for $\mathrm{P}+\mathrm{G}$ cows at every assessment during the study period (Figure 1). For the $\mathrm{P}+\mathrm{G}$ cows, mean BCS increased only slightly between 332 and 612 DIM, but a greater $(P<0.05)$ increase occurred for TMR cows (Table 1).

Mean BW was also greater $(P<0.001)$ in TMR cows compared with $\mathrm{P}+\mathrm{G}$ cows for the duration of the study period (Figure 1). In both groups, BW increased 
between 332 and 620 DIM, but the increase was greater $(P<0.05)$ for TMR cows than $\mathrm{P}+\mathrm{G}$ cows (Table 1$)$.

Note that in Figure 1, the final points for the TMR cows are means from the 3 cows remaining in milk, but the means provided in Table 1 represent mean changes from the initial weighing or BCS assessment to the final weighing or BCS assessment for all 6 cow in each group, irrespective of when that final weighing or assessment occurred (i.e., for cows that dried off early, the final weighing and BCS assessment was at approximately 569 DIM).

\section{Milk Production}

Total yields of milk, milk protein, milk fat, and milk solids (fat and protein) during the extended-lactation period (between 300 and 670 DIM) did not differ according to diet $(P>0.05$; Table 1$)$.

Mean milk yields for TMR cows were slightly greater $(P<0.05)$ at approximately 332 and 392 DIM than for $\mathrm{P}+\mathrm{G}$ cows, but there was no difference overall $(P=$ $0.537)$. Mean daily milk fat yields were not affected by $\operatorname{diet}(P=0.306)$ except at the first sampling (Figure $2)$. Mean daily milk protein yield was higher $(P<0.05)$ for TMR cows than for $\mathrm{P}+\mathrm{G}$ cows at approximately $332,347,392$, and 520 DIM. No differences were found in mean milk protein and fat concentrations between groups (data not presented).

\section{Hormones and Metabolites}

Mean plasma glucose concentrations were greater $(P<0.01)$ for TMR cows than for $\mathrm{P}+\mathrm{G}$ cows (Table 2 ). Mean plasma glucose concentrations gradually increased throughout the study period in TMR cows, but in $\mathrm{P}+\mathrm{G}$ cows, glucose concentrations declined and then recovered (Figure 3 ).

Mean plasma IGF-1 concentrations for the TMR cows were greater $(P<0.01)$ than for the $\mathrm{P}+\mathrm{G}$ cows (Table 2 ). For the $\mathrm{P}+\mathrm{G}$ cows, mean plasma IGF-1 concentrations were constant from approximately 346 to 569 DIM, and then increased at 612 DIM, whereas in TMR
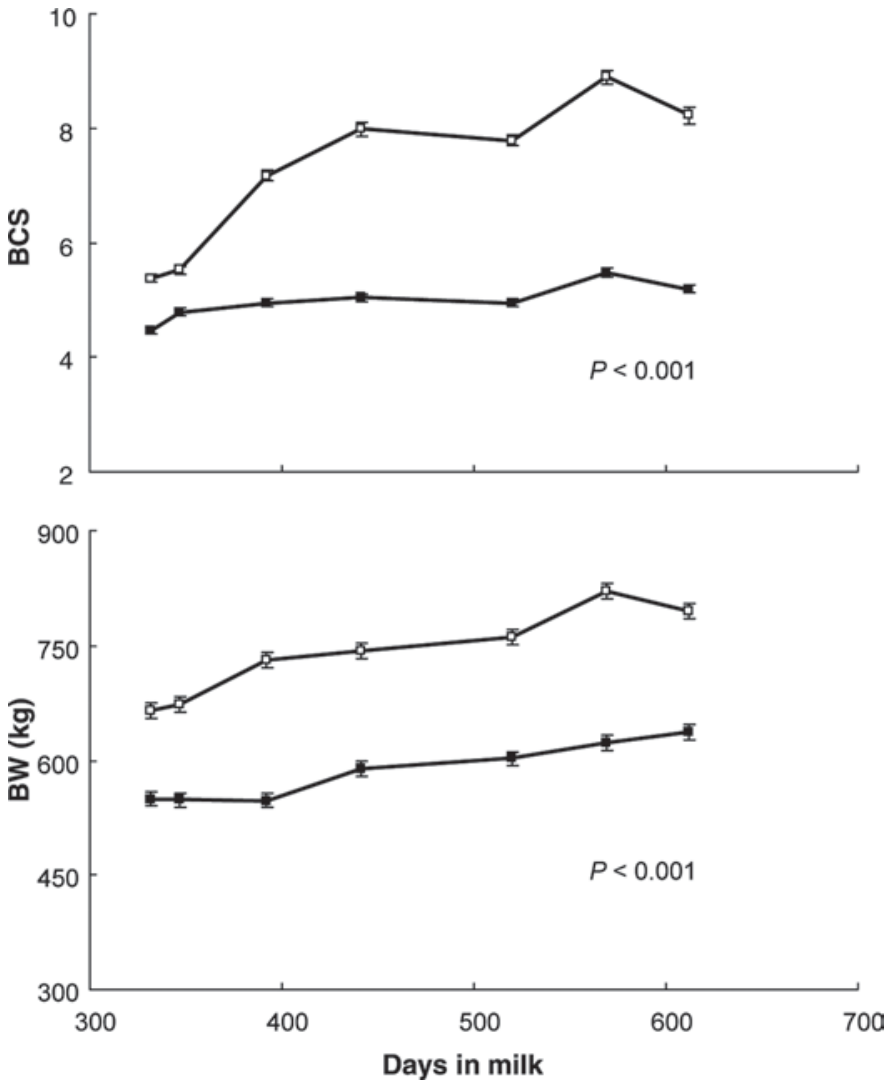

Figure 1. Changes in BW and BCS between 332 to 620 DIM for cows fed a TMR $(\square)$ or pasture-based diet supplemented with grain (ם). Data are means for 6 cows per treatment, except for at the final sampling where $\mathrm{n}=3$ for the TMR cows. Vertical bars represent SEM; $P$-values indicate significance of overall effect of diet.

cows, mean plasma concentrations of IGF-1 increased gradually during the study period (Figure 3 ).

Overall, mean plasma glucagon concentrations were greater $(P<0.02)$ for TMR cows than for $\mathrm{P}+\mathrm{G}$ cows (Table 2). This was due mainly to differences at the last 3 sampling occasions (Figure 3).

Mean plasma GH concentrations for TMR cows were lower $(P<0.01)$ than for $\mathrm{P}+\mathrm{G}$ cows on all of the sampling occasions (Table 2; Figure 3). Differences between

Table 1. Total yields (kg/cow) of milk, milk fat, milk protein, and milk solids (fat and protein), and changes in BW and BCS, between 300 and 670 DIM for cows fully fed on TMR or a pasture-based diet supplemented with grain $(\mathrm{P}+\mathrm{G})^{1}$

\begin{tabular}{lcccccc}
\hline Item & $\begin{array}{c}\text { Milk } \\
\text { yield }\end{array}$ & $\begin{array}{c}\text { Fat } \\
\text { yield }\end{array}$ & $\begin{array}{c}\text { Protein } \\
\text { yield }\end{array}$ & $\begin{array}{c}\text { Milk } \\
\text { solids yield }\end{array}$ & $\begin{array}{c}\text { BW change } \\
(\mathrm{kg})\end{array}$ & $\begin{array}{c}\text { BCS } \\
\text { change }\end{array}$ \\
\hline $\mathrm{P}+\mathrm{G}$ & $5,284 \pm 463$ & $275 \pm 24.7$ & $210 \pm 13.4$ & $485 \pm 37.4$ & $105 \pm 20.8^{\mathrm{a}}$ & $0.9 \pm 0.39^{\mathrm{a}}$ \\
$\mathrm{TMR}$ & $5,036 \pm 830$ & $235 \pm 33.4$ & $197 \pm 31.9$ & $432 \pm 64.8$ & $156 \pm 13.7^{\mathrm{b}}$ & $3.3 \pm 0.14^{\mathrm{b}}$ \\
\hline
\end{tabular}

${ }^{a, b}$ Within columns, means with different superscripts are significantly different $(P<0.05)$.

${ }^{1}$ Data are predicted means $(n=6) \pm$ SEM for the subset of cows used in the current study. Body condition score was assessed by trained assessors using a modified version of the method of Robins et al. (2003). 

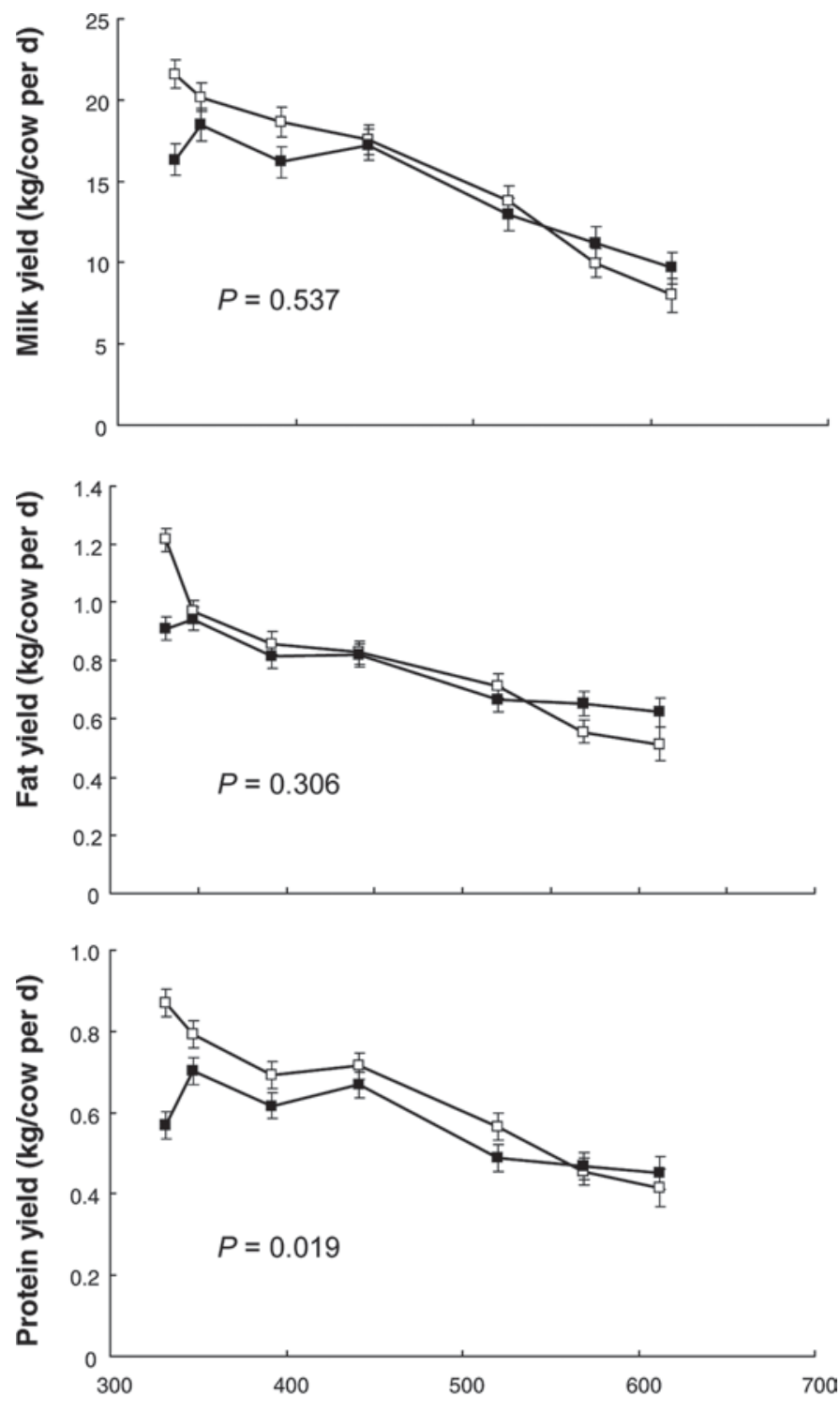

Days in milk

Figure 2. Yields of milk, fat, and protein between 332 and 620 DIM for cows fed a TMR ( $\square$ ) or pasture-based diet supplemented with grain (ם). Data are means for 6 cows per treatment, except for at the final sampling where $\mathrm{n}=3$ for the TMR cows. Vertical bars represent SEM; $P$-values indicate significance of overall effect of diet.

the 2 groups appeared larger early and late in the study period.

Mean plasma insulin concentrations for TMR cows were greater $(P<0.01)$ than for $\mathrm{P}+\mathrm{G}$ cows at all sampling occasions (Figure 3; Table 2). In the TMR cows, a peak in mean plasma insulin concentrations occurred at approximately 441 DIM, whereas for $\mathrm{P}+\mathrm{G}$ cows, concentrations of plasma insulin were steady throughout the study period.
Mean plasma leptin concentrations were greater $(P$ $<0.01$ ) for TMR cows than for $\mathrm{P}+\mathrm{G}$ cows at every sampling occasion (Table 2; Figure 3). For both groups, leptin concentrations increased during the study period.

Diet did not affect mean concentrations of serum NEFA or BHBA $(P=1.00$ and $P=0.275)$. The mean serum NEFA and BHBA concentrations ( \pm SEM) for all cows were $0.54 \pm 0.010 \mathrm{mmol} / \mathrm{L}$ and $0.11 \pm 0.002$, respectively.

\section{DISCUSSION}

This study provides new information about the effect of diet on plasma concentrations of metabolic hormones and metabolites in Holstein-Friesian cows undergoing extended lactations of up to 670 DIM. Differences were found in the concentrations of metabolic hormones and glucose that were dependent on whether cows were fed TMR or a pasture-based diet supplemented with grain. Thus, the primary hypothesis of the current experiment is accepted.

The results of the current experiment concur with the results of a previous study in New Zealand that also examined the concentrations of metabolic hormones and glucose in cows at 440 DIM during a 605-d lactation (Kay et al., 2009). In that study, the hormone and metabolite concentrations of different genetic strains of Holstein-Friesian cows were compared in the context of their ability to sustain extended lactations. It was reported that the strain of cow that preferentially partitioned energy reserves toward body reserves at the expense of milk production during extended lactation (the New Zealand Holstein-Friesian) also had greater BCS, reduced milk production, and greater plasma concentrations of glucose, insulin, and leptin than the strain that produced more milk (the North American Holstein-Friesian). These observations are consistent with those made in the current study for TMR cows, which similarly partitioned energy toward adipose tissue at the expense of milk production and were compromised in their capacity to sustain an extended lactation.

In the study of Grainger et al. (2009), cows fed TMR produced substantially more milk than $\mathrm{P}+\mathrm{G}$ cows in the first 300 DIM. Subsequent to that, many TMR cows were unable to sustain high levels of production and did not produce more milk or milk solids than $\mathrm{P}+\mathrm{G}$ cows between 301 and 670 DIM. Furthermore, the TMR cows gained considerably more BCS and BW than $\mathrm{P}+\mathrm{G}$ cows, and by $600 \mathrm{DIM}$, a lower proportion of TMR cows were still lactating compared with $\mathrm{P}+\mathrm{G}$ cows. Similar observations were made in the subset of cows reported here. 
Table 2. Concentrations of metabolic hormones and glucose in blood plasma from cows fed either a TMR or a pasture-based diet supplemented with grain $(\mathrm{P}+\mathrm{G})^{1}$

\begin{tabular}{lcc}
\hline Item & $\mathrm{P}+\mathrm{G}$ & TMR \\
\hline Glucose $(\mathrm{m} M)$ & $3.3 \pm 0.04^{\mathrm{a}}$ & $3.7 \pm 0.04^{\mathrm{b}}$ \\
Insulin $(\mathrm{pg} / \mathrm{mL})$ & $131 \pm 15.4^{\mathrm{a}}$ & $480 \pm 55.7^{\mathrm{b}}$ \\
Glucagon $(\mathrm{pg} / \mathrm{mL})$ & $26 \pm 2.3^{\mathrm{a}}$ & $46 \pm 5.1^{\mathrm{b}}$ \\
Insulin:glucagon & $5.2 \pm 1.0^{\mathrm{a}}$ & $11.5 \pm 2.1^{\mathrm{b}}$ \\
Growth hormone $(\mathrm{ng} / \mathrm{mL})$ & $1.6 \pm 0.1^{\mathrm{a}}$ & $1.0 \pm 0.1^{\mathrm{b}}$ \\
IGF-1 (ng/mL) & $195 \pm 15.9^{\mathrm{a}}$ & $280 \pm 15.1^{\mathrm{b}}$ \\
Leptin $(\mathrm{ng} / \mathrm{mL})$ & $1.0 \pm 0.1^{\mathrm{a}}$ & $2.3 \pm 0.1^{\mathrm{b}}$ \\
\hline
\end{tabular}

${ }^{\mathrm{a}, \mathrm{b}}$ Within rows, means with different superscripts are significantly different $(P<0.01)$.

${ }^{1}$ Data are predicted means $(\mathrm{n}=6) \pm$ SEM from 7 sampling occasions between 332 and 620 DIM.

The TMR cows had higher blood glucose concentrations compared with the $\mathrm{P}+\mathrm{G}$ cows. This most likely reflected a nutrient intake that exceeded the requirements of the mammary gland for milk production. The high intake of the TMR diet resulted in an increased supply of precursors for hepatic gluconeogenesis. Postruminal digestion of the starch component of the maize silage in the TMR also may have led to direct absorption of glucose from the small intestine, contributing further to high plasma glucose concentrations in these cows (Allen, 2000). In turn, elevated plasma glucose concentrations would have led to the observed increase in plasma insulin concentrations, as was similarly reported by Kay et al. (2009). High insulin concentrations facilitated the preferential deposition of glucose into adipose tissues (Pessin and Saltiel, 2000; Khan and Pessin, 2002) and inhibition of lipolysis in adipose tissue, which contributed to the observed increases in BW and BCS. High plasma glucose and insulin concentrations in heavily conditioned cows may also be indicative of insulin insensitivity (Bergman et al., 1989).

Plasma glucagon concentrations were also higher in the TMR cows compared with $\mathrm{P}+\mathrm{G}$ cows. Glucagon has an opposing role to insulin in that it increases plasma glucose by triggering the liver to convert stored glycogen into glucose. Higher glucagon concentrations in the TMR cows may have contributed to increased plasma glucose in those cows, but no explanation is offered for why insulin and glucagon were concomitantly elevated in TMR cows during the latter part of the extended lactation. Nevertheless, the higher insulin:glucagon ratio in TMR cows compared with $\mathrm{P}+\mathrm{G}$ cows is consistent with insulin secretion being greater in the TMR cows.

The higher plasma GH and lower IGF-1 concentrations in $\mathrm{P}+\mathrm{G}$ cows suggest a greater change in the interactions of the components of the somatotropic axis in these cows compared with the TMR cows. Because plasma IGF-1 is the main negative feedback hormone for GH production (Etherton and Bauman, 1998; Le
Roith et al., 2001), it is possible that the decreased concentrations of circulating IGF-1 contributed to higher GH in these cows, partially through reduced negative feedback. One action of GH is to inhibit deposition of energy substrates in peripheral tissues (Etherton and Bauman, 1998), so a lower circulating GH concentration in TMR cows compared with $\mathrm{P}+\mathrm{G}$ cows is consistent with a greater level of lipogenesis and weight gain in those cows. Nevertheless, differences in GH could have been expected to be associated with changes in the concentrations of circulating NEFA, but this was not observed in the current study.

Plasma concentrations of leptin were substantially increased in the TMR cows compared with $\mathrm{P}+\mathrm{G}$ cows. This is consistent with the study of Kay et al. (2009), in which cows with greater BCS had higher plasma leptin, and also with the fact that leptin is secreted almost exclusively by adipocytes and is thus a marker for adiposity (Zhang et al., 1994; Ahima and Flier, 2000). In accordance with the current results, leptin expression also may be upregulated by insulin (Houseknecht et al., 2000).

Overall, the differences in plasma metabolite and hormone profiles between the 2 groups are consistent with the TMR cows gaining more BCS and BW than the $\mathrm{P}+\mathrm{G}$ cows (Bauman and Currie, 1980). Thus, the second hypothesis is also accepted. The mechanism by which some TMR cows gained excessive weight, reduced milk yield, and dried off, however, is uncertain. It is also unclear at what point in a lactation this mechanism takes effect. In the current study, the 2 groups were already well divergent in BCS, BW, and some hormones by the time of the first sampling at 332 DIM. These important aspects warrant further investigation because of the practical implications for the nutritional management of cows in extended lactation systems.

Around $90 \%$ of Victorian dairy herds consume pasture supplemented with varying concentrations of grain or cereal concentrates as their main feed source, (Dairy Australia, 2010). Consequently, the results of the current study are highly relevant to Australian herds. Economic analyses have shown that, in Victoria, extended-lactation systems can be at least as profitable as systems with seasonally concentrated calving patterns (Malcolm, 2005; Trapnell and Malcolm, 2006). The current study shows that the prevailing $\mathrm{P}+\mathrm{G}$ feeding systems are more likely to facilitate lactational persistency during extended lactation than are TMR systems.

In conclusion, this study has identified some of the associations between plasma concentrations of metabolic hormones and metabolites, cow diet, and energy partitioning in Holstein-Friesian cows during the latter half of an extended, 670-d lactation. Some cows 

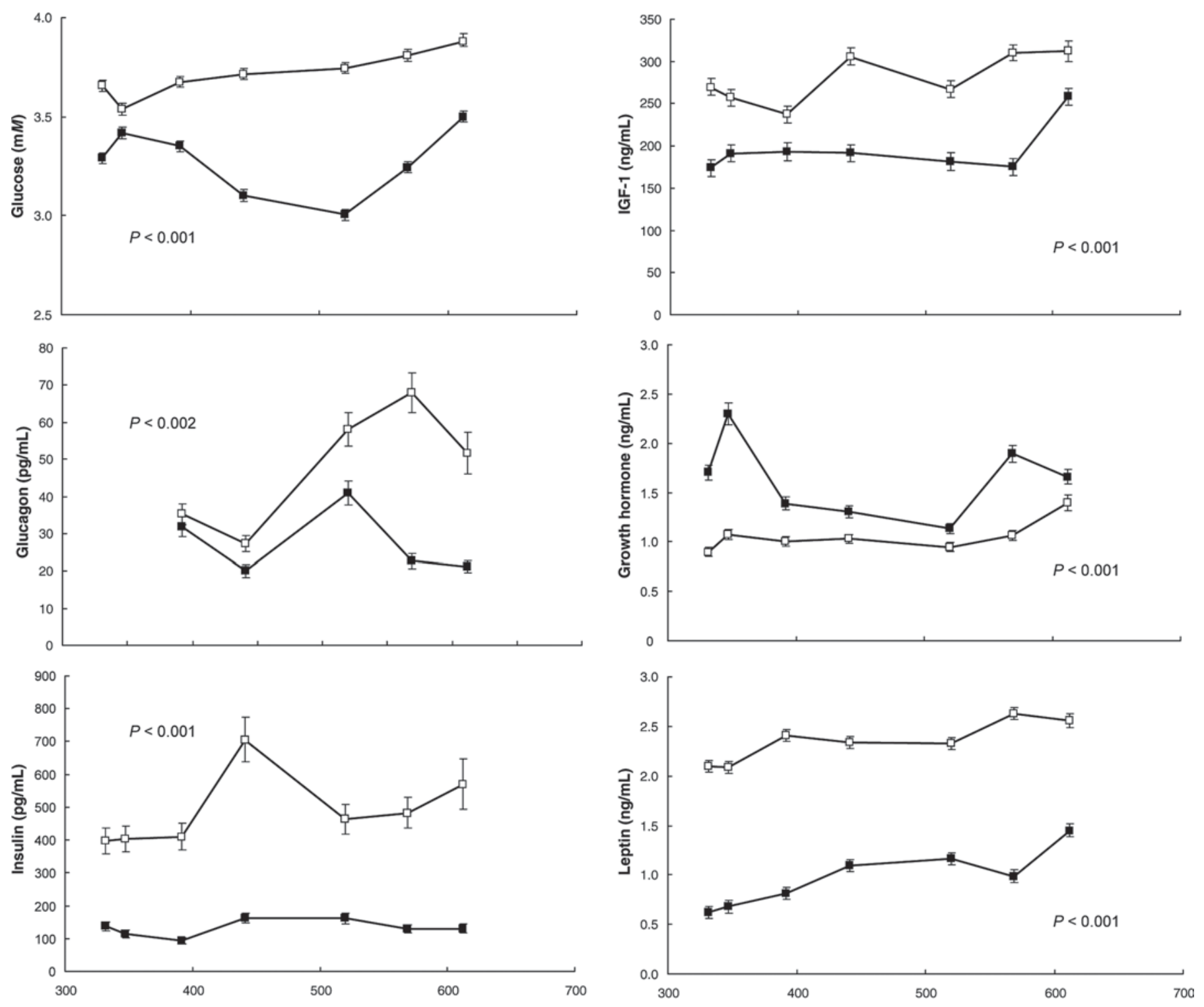

\section{Days in milk}

Figure 3. Plasma concentrations of insulin, IGF-1, glucagon, growth hormone (GH), glucose, and leptin between 332 and 620 DIM for cows fed a TMR $(\square)$ or pasture-based diet supplemented with grain $(\mathbf{\square})$. Data are predicted means for 6 cows per treatment, except for at the final sampling where $\mathrm{n}=3$ for the TMR cows. Vertical bars represent SEM; $P$-values indicate significance of overall effect of diet.

fed to a very high level of nutrition (in the context of Victorian dairying systems) showed a compromised capacity to sustain an extended lactation. In these cows, circulating concentrations of the metabolic hormones IGF-1, leptin, insulin, glucagon, insulin:glucagon ratio, and glucose were elevated, whereas circulating GH concentrations were reduced compared with cows that received a high level of nutrition based on a pasture diet. These observations suggested that the somatotropic axis and blood glucose homeostasis were altered by intake that provided gluconeogenic precursors in excess of the requirements of maintenance and prevailing milk production and ultimately affected energy partitioning toward the udder for milk production.

\section{ACKNOWLEDGMENTS}

The authors are grateful to D. Mapleson, I. Robinson, R. Case, T. Hookey (Department of Primary Industries, Ellinbank, VIC, Australia) and staff at the 
DPI Ellinbank research farm (Ellibank, VIC, Australia) for technical assistance with cow husbandry, grazing management, and sampling procedures. This work was funded by the Department of Primary Industries, the Geoffrey Gardiner Foundation Ltd. (Melbourne, VIC, Australia), Keenan Pty Ltd. (Bendigo, VIC, Australia), the National Herd Improvement Association (Melbourne, VIC, Australia), the Co-operative Research Centre for Innovative Dairy Products (Southbank, VIC, Australia), and Dairy Australia (Southbank, VIC, Australia). Valuable input into the preparation of this manuscript was provided by L. Marett and P. Moate (Department of Primary Industries, Ellinbank, VIC, Australia).

\section{REFERENCES}

Ahima, R. S., and J. S. Flier. 2000. Leptin. Annu. Rev. Physiol. 62:413-437.

Allen, M. S. 2000. Effects of diet on short-term regulation of feed intake by lactation cattle. J. Dairy Sci. 83:1598-1624.

Auldist, M. J., G. O'Brien, D. Cole, K. L. Macmillan, and C. Grainger. 2007. Effects of varying lactation length on milk production capacity of cows in pasture-based dairying systems. J. Dairy Sci. 90:3234-3241.

Baird, D. E. 1994. The design of experiments with covariates. PhD Thesis. Univ. of Otago, New Zealand.

Bauman, D. E., and W. B. Currie. 1980. Partitioning of nutrients during pregnancy and lactation: A review of mechanisms involving homeostasis and homeorhesis. J. Dairy Sci. 63:1514-1529.

Bergman, E. N., S. S. Reulein, and R. E. Corlett. 1989. Effects of obesity on insulin sensitivity and responsiveness in sheep. Am. J. Physiol. Endocrinol. Metab. 257:E772-E781.

Blache, D., R. L. Tellam, L. M. Chagas, M. A. Blackberry, P. E. Vercoe, and G. B. Martin. 2000. Level of nutrition affects leptin concentrations in plasma and cerebrospinal fluid in sheep. J. Endocrinol. 165:625-637.

Borman, J. M., K. L. Macmillan, and J. Fahey. 2004. The potential for extended lactations in Victorian dairying: A review. Aust. J. Exp. Agric. 44:507-519.

Bremmer, D. R., S. L. Trower, S. J. Bertics, S. A. Besong, U. Bernabucci, and R. R. Grummer. 2000. Etiology of fatty liver in dairy cattle: Effects of nutritional and hormonal status on hepatic microsomal triglyceride transfer protein. J. Dairy Sci. 83:2239-2251.

Collier, R. J., J. P. McNamara, C. R. Wallace, and M. H. Dehoff. 1984 A review of endocrine regulation of metabolism during lactation. J. Anim. Sci. 59:498-510.

Dairy Australia. 2010. Situation and outlook. http://www.dairyaustralia.com.au Accessed June 15, 2010.

Downing, J. A., J. Joss, P. Connell, and R. J. Scaramuzzi. 1995. Ovulation rate and the concentrations of gonadotrophic and metabolic hormones in ewes fed lupin grain. J. Reprod. Fertil. 103:137145 .
Etherton, T. D., and D. E. Bauman. 1998. Biology of somatotropin in growth and lactation of domestic animals. Physiol. Rev. 78:745761.

Grainger, C., M. J. Auldist, G. O'Brien, K. L. Macmillan, and C. Culley. 2009. Effect of type of diet and energy intake on milk production of Holstein-Friesian cows with extended lactations. J. Dairy Sci. 92:1479-1492.

Houseknecht, K. L., C. P. Portocarrero, S. Ji, R. Lemenager, and M. E. Spurlock. 2000. Growth hormone regulates leptin gene expression in bovine adipose tissue: Correlation with adipose IGF-1 expression. J. Endocrinol. 164:51-57.

Ingvartsen, K. L., and J. B. Anderson. 2000. Integration of metabolism and intake regulation: a review focusing on periparturient animals. J. Dairy Sci. 83:1573-1597.

Kay, J. K., C. V. C. Phyn, J. R. Roche, and E. S. Kolver. 2009. Extending lactation in pasture-based dairy cows. II. Effect of genetic strain and diet on plasma hormone and metabolite concentrations. J. Dairy Sci. 92:3704-3713.

Khan, A. H., and J. E. Pessin. 2002. Insulin regulation of glucose uptake: A complex interplay of intracellular signalling pathways. Diabetologia 45:1475-1483.

Kolver, E. S., J. R. Roche, C. R. Burke, J. K. Kay, and P. W. Aspin. 2007. Extending lactation in pasture-based dairy cows: I. Genotype and diet effect on milk and reproduction. J. Dairy Sci. 90:5518-5530.

Le Roith, D., C. Bondy, S. Yakar, J. L. Liu, and A. Butler. 2001. The somatomedin hypothesis: 2001. Endocr. Rev. 22:53-74.

MalcolmB. 2005. Economics of extended lactations. Aust. Farm Bus. Manage. Network J. 2:110-121.

Menzies, K. K. 2008. A role for insulin to increase milk protein production. PhD Thesis. Univ. of Melbourne, Australia.

Moyes, T. 2004. Variation in concentrations of insulin-like growth factor-1 (IGF-1) in pasture-fed Holstein-Friesian cows. PhD Thesis. Univ. of Melbourne, Australia.

Nocek, J. E., W. P. Kautz, J. A. Leedle, and E. Block. 2003. Direct-fed microbial supplementation on the performance of dairy cattle during the transition period. J. Dairy Sci. 86:331-335.

Obese, F. Y., A. R. Rabiee, K. L. Macmillan, A. R. Egan, S. Humphrys, and G. A. Anderson. 2008. Variation in plasma concentrations of insulin-like growth factor-I in pasture-fed Holstein cows. J. Dairy Sci. 91:1814-1821.

Pessin, J. E., and A. R. Saltiel. 2000. Signaling pathways in insulin action: Molecular targets of insulin resistance. J. Clin. Invest. 106:165-169.

Robins, C., R. Stockdale, J. Crosby, and J. Morton. 2003. The Condition Magician: Body Condition Scoring in Dairy Herds. Department of Primary Industries, Melbourne, VIC, Australia.

Trapnell, L., and B. Malcolm. 2006. Economic analysis of changing from a 300-day lactation to an extended lactation system. Proc. Bienn. Conf. Australas. Farm Bus. Manage. Network, Marcus Oldham College, Geelong, VIC, Australia.

Williams, J. E., S. J. Miller, T. A. Mollett, S. E. Grebing, D. K Bowman, and M. R. Ellersieck. 1987. Influence of frame size and zeranol on growth, compositional growth and plasma hormone characteristics. J. Anim. Sci. 65:1113-1123.

Zhang, Y., R. Proenca, M. Maffei, M. Barone, L. Leopold, and J. M. Friedman. 1994. Positional cloning of the mouse obese gene and its human analogue. Nature 372:425-432. 